\title{
Intercultural Balinese Painting from the Classic to the Modern
}

\author{
IWAYANSETEM \\ Department of Pure Fine Art, Faculty of Fine Art and Design, \\ Indonesia Institute of the Arts, Denpasar, Indonesia
}

\begin{abstract}
This article examines the representation mode painting like a change parallel to the profound transformation of the technical or theoretical knowledge, and also parallel to changes in the Balinese society values due to the physical evolution and the evolution of the system of values. In fact, within one century of painting it has been like moving from the classical, traditional, standard, homogeneous, local, and collectively turned into a painting that has been varied, heterogeneous, individual, and internationally with a modern twist. These waves of change occurred in the span of time through several stages, and most striking result from cash capitalistic economy and culture, especially tourism. In pre-colonial time the painting is a narrative religious functions until the time of breath commercialism modernist touches to always make innovations or changes. From the sacred space of temples and palaces to moving objects souvenirs, hotel interiors, fashion and even interior and exterior car. Developments of painting through innovation should not be interpreted as a discontinuity (rapture) or discontinuity of the local context, but on the contrary, to appreciate again the classical values (pastiche), not by road of preserving it rigidly, but the process of reinterpretation and re-contextualization.
\end{abstract}

Keywords: Intercultural, reinterpretation and recontextualisation

Culture at a time will change. At least there are two things that become the cause of cultural change. First, is the occurrence of environmental changes which may require changes in culture that is adaptive. Second, the occurrence of contacts with other nations which might lead to acceptance of foreign culture so that there was a change in values and behavior of the existing layout. The ability to change an important trait in human culture (Haviland, 1988: 251).

Culture of each ethnic group varies according to the nature of culture itself. Therefore, any changes made to vary. In this case, the factors that influence the process of change within a specific culture including just how far a culture support and agree to the flexibility, the needs of the culture itself at a certain time, and most importantly at the level of compatibility between elements of the new and existing cultural matrix. Changes in culture can be run in a slow, somewhat longer, and faster.

Tradition is defined as a form of work, style, conventions or beliefs presented as a continuation of the past into the present. Tradition, therefore is something that never changes, and is run as a repetition (repetition). Tradition is the 'repetition' and 'reproductiion'. The tradition was continued from one generation to the next as a knowledge and truth, which need not be questioned or reinterpretation. This is the conventional notion of tradition.

In the conventional sense, the merging of tradition and change in terms (change) - such a change or development of the tradition - to produce a semantic contradiction. Whereas, the tradition is a reproduction or a continuation of the past, and he will lose if he changed the nature of tradition. The changes are considered as enemies of tradition, which threaten the authenticity, authenticity and sustainability. Likewise the term merging of tradition and development, because when the tradition developed, then of course he was not a tradition anymore. However, many see that the conventional understanding that is not true, because in the course of time there is always an interpretation and reinterpretation of tradition, and he still called tradition. 
Art in Indonesia is a reflection of a very large diversity. Geographical and historical factors obstruct the homogeneous development of the arts with the direction of a single evolutionary line. Cultural phenomena present in the levels of a different life. Some seem ancient but still vital, in other parts appear old and already seems to be extinct or experiencing radical transformations, while another part of the new born and grew up with great and fast (Holt, 2000: $\mathrm{xx}$ ).

In the continuum of cultural growth, the elements overlap the old and new, mixed, or sometimes be present side by side. These figures are only the year that marks the approximate divisor introductory ideas or new techniques, without needing to be explained about the disappearance of the beliefs and habits earlier. For that we need the renewal point of view in observing the art of painting in Bali.

"The future way of thinking and attitudes needed a new perspective view of tradition and modern art as a continuum or a continuum (continuum). Entering the third millenium barriers between tradition with modern art will be even less clear (blurred). Due process of globalization, cultural interactions (including painting), both among the peoples (inter-cultural) as well as between ethnic groups (intra-cultural), thus becoming familiar artistic differences increasingly blurred due to the interaction process, adaptation, adoption, and even by the "marriage" of the various elements of cultural arts.

In the next context is impossible Bali where Balinese survive as at first, because of the influence brought by the tourists and other newcomers. The tourists must carry their own culture, which is also not necessarily in accordance with the Balinese culture. Tourists tend to bring the modern culture and the Balinese culture thick with tradition. Influence of a difference can occur in all sectors of life including in the field of painting.

Not a few researchers both within and from abroad have been researching the existence of painting in Bali. Referring to the opinion of Stutterheim in Claire Holt (1967), divides the ancient Balinese art into three periods, namely 1) Balinese Hindus Period, from the VIII century until the X century, "which had been borrowed directly from the Indian influence (Bud- dhism), or the influence of Java or second, carving a truly Indian character created “, 2) the Bali Kuna, X century until the XIII century. "A definite Indian influences, adapted and combined in an art which clearly becomes inevitable Bali and with more primitive in the beginning of the period which preceded the arts, 3) Central Bali periods, evolved over the centuries XIII and XIV, forming a transition to the arts modern Balinese (Holt, 2000: 244).

Similar to what was recorded Jean Couteau pre-colonial Balinese art is the legacy of an agrarian order Hindu-Buddhist ideo-religious culture that developed in Bali since at least the $\mathrm{X}$ century, when the establishment of the kingdoms' was India's “first. Variety of pre-colonial Balinese culture is a blending between the local indigenous elements with various elements of the mainly Indo-Javanese Majapahit year signed following the 1343 invasion. Painting that was known at that time was dominated by the genre of "puppet”, which is a good illustration of narrative or story iconography derived directly from the art of puppetry (Couteau, 2002: 106).

In discussing the painting like a mixture of art manifestation ethnic Balinese with a variety of influences, should once again citing the description Jean Couteau, invasion of the Netherlands in 1845-1848 and 19061908 in North Bali South Bali, crushing all political foundation of pre-colonial Balinese art . The evolution of art starting in Buleleng Bali (North Bali), although involving a secondary aspect. In the early nineteenth century had created a picture of a paper that contains one scene alone and not the full narrative that displays a series of different narrative scenes. At the end of XIX century in Singaraja, Van Der Tuuk a Dutch linguist ordered some pictures on, and the image is already showing the beginning of the structuring of space, replacing the iconic elements of the parallel placement both horizontally and vertically. In the twentieth century sculptor, sculptors Buleleng has placed a new mathematical elements, such as carving relief of people cycling in the temple. It is already showing the new elements in order of Balinese art (Couteau, 2002: 106).

Painting is one of the elements of culture that has been and is in the process of change due to intensive interaction with various arts of other peoples, so the form of painting has become inter-cultural. Painting 
since the beginning of its growth can not be separated from the influence of other nations so that the art of painting was born a classic. Denture-denture other national cultural expression has been influential on classical painting Kamasan puppet can not be separated from the Indonesian art of travel.

So also the role of Rudolf Bonnet and Walter Spiese who came to Bali. R. Bonnet and W. Spiese is foreign artists who put great attention to the artistic sense in Bali. They form associations involving artists, communities, village leaders, and the culturalist approach and consultation with various parties, especially those in authority Puri Ubud, finally associations formed in the 1930s under the name of "Pita Maha" (Kusnadi, from 1990 to 1991: 255). "Ribbon" means noble and "Maha" meaning great, so "Pita Maha" means the bond of the sublime and beautiful artist. The purpose and objective is to promote and develop the noble values of works of art and artists raised the welfare. Pita Maha” become a place of Balinese artists to develop their creativity. West blend of modern aesthetics with a classic aesthetic that is based Balinese Hindu religion.

Modern aesthetics brought by Western artists R. Bonnet and W. Spies accumulate the concept and function of religious art into profane space that lead to the expansion of the theme of the puppet into everyday objects, introducing the spirit of the individual as well as introducing commercial value. The dynamics of this culture gave birth gendre paintings that show the existence of such a new painting style of Ubud, Batuan, Young Artist, Keliki, Sanur and others.

Surrounding the 1950s show the academic movement in art. This arises from the aspirations and ideas of the younger generation who want a refresher in the form of artwork. Thoughts and aspirations of the birth the idea of establishing schools of art. Artistic conception began with a clearly formulated verbally in the form of books written on the catalog.

In the era of New Order government in 1966, with policy development programs in various sectors, especially the policy of the government program, launched in Bali as a tourism area in the eastern Indonesian region. In line with the program starting capital owners to invest in Bali to support the devel- opment of the tourism sector with the emergence art shop and gallery to accommodate the creativity of artists.

Inter -cultural painting in Bali, which is marked by such an intensive interaction with various influences and then combined with the concept of ethnic Balinese painting. This is a inter-cultural discourse in the arts world, from ethnic to a new tradition that is the area that stores various recordings 'intercourse' between ethnic arts with other artistic influences.

\section{THEORY BASIS}

\section{Evolution Theory}

In outline the theory of evolution describes the development of society as follows: first, social change is considered to be unidirectional rectilinear movement, in other words mass already clear before the world community and can be predicted that at some point later in a relatively long transition period, the world will become forward. Second, the theory of evolution mixing between the subjective view of value and the ultimate goal of social change. Changes in modern society, is something that can not be avoided, by modern society is a form of society which aspired, which contains all the elements of the so-called good and perfect in it there is what the theory of evolution is also considered that current social changes slowly and gradual (Suwarsono, et al. 1994: 10).

Theory of Evolution in this paper look at the movement of the development of classical painting in Bali, from ethnic art (wong-tunnel) gets from Java intercultural (Majahpait) became classic puppet Kamasan painting, moving backwards in the influence of colonial and now bear a variety of art tourism " genre ". It shows the evolution from ethnic to classical, traditional, modern, post modern fired. Changes not only in terms of form but also the function and meaning shifts as part of evolution they experienced.

\section{Conflict Theory}

The conflict is essentially a social phenomenon inherent in the life of every society which is affected by the power, order, interest, domination and hegemony. Conflicts in society always have the degree and pattern of each that is caused by three sources, namely 1) competition over resources, the means of 
production and employment, 2) expansion of the social boundaries of cultural and social identities and political interests, 3) collision political interests, ideologies and religions (Pitana, 2004: 21-22).

In that position of conflict by artists in Bali in absorbing modern ideas brought by tourists (made to order), whereas previously the painting artists accustomed to working on a classic style / tradition is confronted with the demand for tourism taste works so that a conflict of ideas in the disclosure form / format painting.

\section{Modernization Theory}

Modernization is defined as the process trasformation In order to achieve a modern status, structure and traditional values in total should be replaced with a set of structures and modern values. For this case as quoted Hungtington in Suarsono et al. stated that the modernization of traditional and modern view as two concepts that are basically incompatible. In this case the theory of modernization describes in detail what were the characteristics of modern society, while the characteristics of traditional society to discuss forgotten. By basing ourselves on the formulation of a theoretical framework and methods oo study, modernization can reduce the implications of development policies that need to be followed by a third country in an effort to modernize itself (Pitana, 2004: 2324).

By using this theory can be observed changes in the beauty of the painting like a classic beauty that moves into the modern. Modern art is art that always show the new reality is not limited by style and a certain style, but the expression and spiritual attitude that is based on the spirit of their creator exploration, equipped with a frame of reference of the western aesthetic information.

\section{INTERCULTURAL PAINTING BALI}

The term is more unpopular than trans-cultural. inter-cultural and multi-cultural, as described (Nieto, 1992: 48). This term seems appropriate in an effort to reach a dialectical exchange between cultures. This term does not by itself indicate that it contains two cultures come into contact with each other in it, but he can have two different cultures interact, stimulating and answer the questions a person against an- other person. This term will be useful in seeing "banging" culture that has played an important role for hundreds of years. While the term trans-cultural and multiculturalism do not show more clearly the dialectic process. These two terms can reach beyond the scope, but this term can not display a mixture of "ingredients" of different cultures.

Inter-cultural is diversity and cross cultural issues faced by every community and public awareness of open intercept. This term refers to the process of cooperation, interaction and intersection between cultural groups. Cross-cultural obtain a new dimension with respect to intensive cross-cultural contiguity either because the process of globalization and the media revolution. Contiguity between cultures, not just beyond geographical boundaries, but also crossed in the time dimension is moving into the past and the future. Compaction of space and time in the process of cross-cultural, natural disassemble the transmission value which is usually passed down from generation to generation (Rahzen, 1999: viii).

Rustom Barrucha asserts that inter-culturalim is autonomous. Nor is it a fair game, so far in practice made possible through an exchange with an unfair basis. To this day continues to be inter-cultural theory, rhetoric, concepts, frameworks, maps, and funds, almost all first-world location (Barrucha, 1999: 14).

For the term multiculturalism is understood as there is an emphasis on race, referring to the diversity that shows harmony, but ignoring the problem of language and culture (Good, 2001: 9-11). As a result it will lead to conflict such as Indonesia. For the concept of inter-cultural must be understood as something that is not defined solely as between racial pluralism, but also as a reaction that includes culture, language in a more detailed review primarily related to the emergence of dominance strength between one language with another language. So the proposed direction of I Gusti Ngurah Bagus is a balance between the interests of certain ethnic with other ethnicities interact.

Inter-cultural is not kill the process of ethnic cultures, but trying to integrate ethnic culture with other ethnic thereby creating something new appears and can be enjoyed by all ethnicities who support them. Ethnic culture is alive and growing in accordance with 
its function. Creation of something new it will add a richness of cultures that exist in Indonesia. Here's the changes will be visible.

\section{Process Intercultural Balinese Painting of Mod- ern Ethnic Up Post}

1. Establishment of painting to become a classic (Kamasan).

Habits in the days of Hindu painting is mentioned in the Hindu-Javanese literature. How did the tradition of drawing and painting style in the days of the Hindu's lack of explanation. Sculptures to decorate the temples of East Java is important to stand as a source of introduction of the Hindu era painting (Yudoseputra, 1990-1991: 40).

Since the Bali tread familiar with the history of puppets. When the reign of King Ugrasena (896. M), in one of the terms mentioned parbhwayang prasasti there. Further around the XI century (1045-1047), in inscriptions issued by King Child Wungsu Aringgit there are terms and there are scratches motive batara puppets depicting Shiva. This gives clues have known the existence of groups that have a skill to paint puppet (Kanta, 1975: 6).

The inscriptions which mention the existence of puppets, namely: the inscription Bebetin A 1, No. 002, reads: “... Pande copper, puppet, singers, bat sounds, drum beaters, piper, masked dancers, puppeteers (parbayang) ... dropped in Panglapuan in Singamandawa in X, the day-to $\neg 5$ poro light on, day trades Manggala Wijaya, Çaka 818 years.

Supposedly the writers of the early puppet home his first of the artist, primarily painting and sculpture that want to realize content epic story of Ramayana and Mahabharata. Then made by the artist's paintings in the form of men decorated palm leaves with carvings, coiled, necklace, bracelets, earrings and other. The shape and face painting was adjusted with the character or nature of the painted scenes or actors. To add a beautiful color painting was given in accordance with the nature of the perpetrator.

In the manuscript of Kekawain Udayana No. 691 collections of the Faculty of Letters Udayana University are mentioned:
Dening loka... ngalem to the Bhujangga pinuji, ndan sayunanira the most initiative Prabhangkara winuwus, Muang puzzle wenten wicak sanani the Bhujangga karengo, ira tuladen sasing Nika color ring kawaka yadian piteki giant god denawa pisaca tui, mwang stryarja neleming sara niyata makewehanira tan ....

Meaning:

... By the people to respect all the Bhujangga commendable expertise, as for the title of his very Masyur Prabhangkara. This is no longer the Bhujangga expertise, all that art can imitate drew (painted), although the giant, deities, demons, gods and beautiful daughters, who in

praise of the world he is certainly not difficult by painting ...

In the palmyra manuscript Tantu Pangelaran No: 48 there is mentioned Bhagawan Ciptagopta painting, marna amadna-ri Lanka Soka rupaka copyright crana mpune tanganta, matangnian. Mpu Ciptangkara ngaranta angelukis ...

Meaning: Bhagawan Ciptagopta painter, concoct sentences, and then realize the creation of his thumb, that's why .. Mpu Ciptangkara name as a painter (Kanta, 1975: 4-5)

To interpret the terms of the puppet's current form we have seen historically, that Bali has long been in contact with the East Java since the VIII century Dalem Kanuruhan's government. The relationship among the biological father of King Children Wungsu namely: Dharma Udayana Warmadewa who married the CRI Guna Dharma Patni Priya, daughter of the descendant Makutawang Sawardana Sindok.

From the facts above, the form of a puppet in the Balinese Hindu culture is the result of acculturation, especially Java, East Java, particularly the influence of Majapahit and Kertanegara. Other statements mentioned in the Babad Dalem, that in Gelgel, King Cri Dalem Kepakisan never went to Majapahit and the return received a prize from the royal Majahpahit form: kris Begawan Canggu, belts worship Keropak Jagat and leather puppets (Kanta, 1975: 7).

Furthermore, in ancient texts can be found in the form of papyrus paintings are still popular puppet people of Bali. Picture in miniature palm is a beautiful painting, which is done by means of sharp-edged knife 
that carved above palm leaves a very small format, compressed elongated about $2 \mathrm{~cm}$ to $8 \mathrm{~cm}$. Trenches are created from scratch knife, then smeared the mixture of oil and soot.

Painting style in this palm seems to be a forerunner to the development of painting that developed the classic puppet Kamasan XV century, and very advanced during the reign of King Delem Waturenggong. The emergence of wong-wong painting or classical painting Kamasan Wayang Kamasan starting perintahan Gegel fall and moved to Klungkung in the year 1686 AD The collapse of the empire Gelgel into the hands of the power of Gusti Agung Dalem Maruthi Made resulted in the rise in morale for the children to take back Kraton Sweca Pura Gelgel.

Once Dewa Agung Jambe holding of government, the center moved to Semarapura kingdom, and there Dewa Agung Jambe its staff to continue and deepen the knowledge of the Dharma (Hinduism), literature, philosophy, and art. Especially in the field of arts, Dalem Klungkung was very concerned and aegis and guidance to the painter in Kamasan. So famous names Modara Sangging Gede, who until now considered an elder by the artists in Kamasan. A priceless gift, and in the long memories given to the kings of subordinates (Kanta, 1977 to 1978: 10).

Kamasan painting at that time with the artists were very high quality trusted by the community. This is thanks to Klungkung legetimasi and services introduced to all corners of this puppet painting Bali island, so that the developing en masseThe artists were able to become role models for the pattern of Balinese painters. The guidelines of this visualization becomes stronger due to implemented with the awareness by Balinese artists who consider art as a gift from Ida Sang Hyang Widhi Wasa, taught by the Gods and Goddess to comply with the provisions tatwa (philosophy of) religion. A similar view to understand the work gave birth to "obey" the rules with the principle of service (working without vested interest) through the "intention" sacred, so no need to write names on each of his works. The painter was pleased when his work copied, regarded as the dharma bhakti for the public interest.

Kamasan is a classic painting works of art whose beauty enjoyed through the visual, an expression of the artist's starting point in the story of puppetry. It says "classic" because it has already reached its peak. The peak of its power seen in other forms of puppet figures are displayed with all the attributes which decorate it. Form of figures and attributes were already a standard thing and agreed by the general public.

\section{Distribution and development in Ubud}

While in Ubud painting that closely resembles that developed the classic Kamasan painting. The rapid progress experienced when it comes Ubud painter painter foreigners such as Walter Spies settled in Bali began in 1927 and the agreement of Klungkung with Tjokorda Gede Agung Sukawati to make contact with cultural and foreign artists who are interested in Balinese art. Wallter meeting Spies and Rudolf Bonnet with Balinese painters not only produces a change in art style and attitude for the painters of Bali, but is able to raise the degree of the constellation of $\mathrm{Ba}$ linese painting into the art world.

In the beginning was the violist Walter Spies came to Ubud at the invitation of the king of Ubud, Tjokorda Gede Agung Sukawati. Introducing the King of Ubud with Walter Spies kekratonan occurred while attending a ceremony in Yogyakarta. But while in Ubud, Walter Spies was very interested in the natural beauty of life is supported by the cultural arts. Seeing the painting in Ubud, which has a specific value so that it appears its intention to sell the paintings to his guests. From the results of activities to promote the work of these artists, the more open-minded to appreciate a work of art. Results Ubud artists can still be developed in terms of anatomy and perspective, besides the artists are also expected to put a name on his work. Indirectly, the existence of an individual touch in the art.

Walter Spies painting eventually join while providing guidance to the artists in Ubud. Campuhan he settled in Ubud, so that mutual interaction content filling in the works. Paintings by Walter Spies also indirectly affected by the nature and culture of Bali, and then reverse the work of artists in Ubud painting style was influenced by Walter Spies. He pursue decorative motifs with which sometimes surialistis dissemination. With the intercession of Tjokorda Gede Agung Sukawati, Walter Spies foster painters Ubud and its surroundings, providing notions of freedom in choos- 
ing the title of everyday human life, in the preparation of light to dark gradation abur technique (the technique of color with layers of Chinese ink), the term perspective with which to see birds flying from the direction of the object and something that seems increasingly distant as well as the smaller the human form in the elongated proportions.

While the painter Rudolf Bonnet to his naturalistic style, giving the effect, the proportion of anatomy, and in making objects closer to reality. Rudolf Bonnet as pemerakarsa establishment of "Pita Maha" in the date January 29, 1936 (Catalogue of the museum, 1984) and the establishment of the museum Ratna Warta Museum Ubud.

Reform movement "Pita Maha” Walter Spies guidance and dozens of artist Rudolf Bonnet produced qualified, divided into multiple streams that include both rural sculpture and painting. Education is the goal of this organization to build and develop the potential of the artists artwork. "Pita Maha" was also called the agency that sets standards of artistic works of the artists whose role as a promoter and marketing his work. Its members are not limited to the artists in Ubud, but until Klungkung, Denpasar, Sanur.

Gusti Nyoman magnate is Lempad, an undagi (architect), so aware of the technical capabilities of the medium of paper, lifted the black-and-white painting to a level that has never in its original state. At work Lempad Manjadi line encyclopedia, he exists for the sake of aesthetics alone, and not just linear as a mere illustration of the support that is different from precolonial style. Another important figure is Anak Agung Gede Sobrat whose career showed impressive stylistic evolution.

\section{Distribution and growth in Batuan}

In the village of Batuan Sukawati district, developing a traditional painting style is somewhat different with Ubud. S type decoratively arranged in such a way that seems very detailed. The colors are applied in the works give the impression more dense and slightly darker by applying techniques manggsi Sigar, so that visually displays the form of a spooky, magical and terrifying, and the paintings reflect a certain atmosphere of the night, reminiscent of a dance or drama gambuh performed at night. Paranan line was so dominant as a barrier field-painted with painstaking.
This style has been started since the 1930s, where the work of artists is more like a watercolor or tempera on paper.

The characters of this rock style of painting, among others, I Patra, I Ngendon, Ida Bagus Togog, Ida Bagus Made Wija, and others. Painters I Ngendon and Ida Bagus Togog including the first painter who adopted the human anatomy as taught her Bonnet. Two of these painters became a pioneer, opening the way to introduce the theme-the theme of everyday life in paintings.

A.A. M. Djelantik (1996) describe the painting style of rock, can be divided into three genres. First, it can be seen from the descendants of the family of the late Ida Bagus Togog which according to tradition inherited skills as craftsmen, depicts the stories of Ramayana and Mahabharata or mythological subjects. Having been a member of "Pita Maha", he also received guidance Rodolf Bonnet and Walter Spies. He paints on canvas in large sizes (Djelantik, 1996: 17).

Second, we can see Made Djata who likes to create large-format works, describes the mythology and stories plus a wealth of imagination and puppet fantasies own. Painting-shaped island of Bali with all its paraphernalia of detailed, starting from I Djata subsequently influence other artists such as, Made Body, Rajin Wayan, Made Bukel, Sujendra, and god Mandra.

Third, the can be witnessed from paintings seasoned with humor, witty, which is good reactions about modern life, especially the tourism industry in Bali with all its aspects. In a naive style, but done with the craft was still perfect and sensitive artistic instinct, theme-theme paintings on the image range from bicycles, cars, airplanes, helicopters combined activities depicted religious ceremonies and at random, funny, and exotic.

4. Distribution and development in Sanur .

Dutch expedition landed in Sanur in 1906 to strike the earth, under the pretext of Badung Sri Komala ship seized by local residents after a beached due to the enactment Rights Tawan Sanur Reef. After Badung conquered and occupied, and Dutch empires intensively promote Bali in Europe and America. Bali 
The Last Paradise promised by found a dream in which beautiful, beautiful nature, customs and cultures that live beats. This campaign will open the eyes of the western world the beauty of the cultural richness of Bali.

Since the 1920s the Europeans coming to Bali with in the KPM ships(Koninklijke Paketvaart Maatschppis / Royal Dutch Shipping Company) as a travel agent tour, which landed in Sanur. The first time the Dutch came J.A. Houbalt lived and settled near Pura Mertasari very sacred by the local community. But he did not stay long because the unfortunate house fire. After that some dealers and artists to create a place to live on the coast of Sindhu, Sanur. Neuhaus brothers (Hans and Rolf Neuhaus) is a German who came to Bali in 1935 with his mother. When he was in Gilimanuk, Jembrana they met with the Walter Spies, who suggested in an attempt to make a living, Sanur area is the ideal place. Finally Neuhaus Sindhu brothers lived on the coast and open businesses souvenir shops selling ceramics, sculpture and painting eventually sold (Viker, 1998: 9).

Birth of paintings in Sanur partly conditioned by the culture of generosity that has the ablility of Neuhaus brothers in marketing. The results of the Pita Maha artists marketed in Sanur area by Neuaus brothers because he is more able to cooperate with KPM and contact the Bali Hotel as the inn's greatest moments.

According to the documentation Betenson-Mead, there are more than 60 people became a painter in Sanur (1960). Prominent painters, among others: Ida Bagus Rai Griya, (Pedanda Wayan Mas), I Gusti Made Pitja, Ida Bagus Nyoman Rai, I Gusti Made Oka, Ida Bagus Soenia, Ida Bagus Lake and others.

After World War II, Neuhaus and Walter Spies brothers because a German citizen, then imprisoned by the Dutch government. Neuhaus was exiled to India, while Walter Spies was one of the bombing victims of the ship-transport ship Van Imhoff Tawana from Padang to Sri Lanka (Ceylon), which was bombed by Japanese aircraft near kepulawan Nias in 1942. With the loss of brothers Neuhaus painters Sanur lost art patron. Some of them switch this profession for their livelihoods.

Around the year 1946 a Dutch citizen named Koopman founded the gallery in the Sindhu, Sanur was followed Jimmy J Pandy a travel agency Thomas Cook from Surabaya at the same time establishing Galleries shelter. Galleries grows like a fresh breeze for the artist to return to work in Sanur. Thus, Sanur has long been presented as a thirst-quenching springs many great artists creative and stimulating environment for the birth sederatan masterpiece.

The growth in Sanur painters can not be clearly separated by the economic culture (culture economy), will be able to show the truth more accurately: the dynamics of the market, especially the tourism market will develop unidirectional and complementary. The continuity of the growth pattern of the 1930s when the brothers held the veins Neuhaus market, it still lasts to this day.

\section{Developments in academic painting}

After Indonesian independence in 1945, the life of painting in Bali began to be replaced by formal academic education, particularly through the Art of Higher Education. In this institution held the teaching-learning process is ideal in order to produce graduates qualified, independent and able to provide the aesthetic and intellectual enlightenment to the general public.

In academic education given to the ability of graduates to apply these concepts into works of art (in practical terms), and gives the ability to apply concepts into works of art or a scientific study (theoretical level).

Many artists have a new enlightenment, particularly on intellectual, penggayaan insight knowledge, spirit of good exploration of materials, techniques expanded. Contact with the library and other media that provide information about Western painting (modern) and the interaction cross itnik placing the painters play in the same field painters various regions in Indonesia. As a result of the efforts to search for new artistic language that is personal, related to cultural issues, multicultural and political.

Thus in the 1970s until now in Bali appears a new generation of talent that combines formal education of academic excellence from the Institut Teknologi Bandung, STSRI “ASRI” Yogyakarta, Indonesia Institute of Arts Denpasar like Nyoman Tusan, Gunarsa, Made Wianta, Wayan Sika, Pande Gede Supada, etc. Made Djirna. Especially in Bali in 1992 majoring in 
painting opened at the High School of Art Indonesia Denpasar (ISI Denpasar now) able to grow more vibrant artistic activity. The students formed a group for intensively and personally held exhibitions.

This academic movement that does not mean academically graduated artists, but also the artists who have systematic thinking in the process of work. Modernization in the field of art is a reflection in an effort to reform, seeking new possibilities in exploration through expression. This arises from the aspirations and ideas of the younger generation who want a refresher in the form of artwork. In modernization theory to explain, that the point of view (vision), which became the main mode of analysis to the human factor in society. Modernization among the community into a kind of commodity that puts the mentality factor changes. And not far from the modernization of science and technology (Salim, 2002: 67).

The things that are classic or a local tradition in art and became an academic strength in its development. Like the painting like an artist first developed by packaging Gunarsa with modern art and even post modern, bringing refreshment in his artistic creativity by using puppets object which is a development of classical painting Kamasan puppet.

Already complete, because the layers upon layers of intercultural painting like from classical to modern post has been represented in the context of the journey. Any age or era, has the task assigned with specific reasons. This trend of strong powerful in optimizing the potential of art and the continuing validity of a more concentrated with patriotic spirit is fostered by.

\section{REPOSITIONING BALI PAINTING FOR CREATING ADVANTAGE}

Painting as a local culture in the era of economic globalization, and cultural information today is in an attractive condition or 'stress' (tension) in relation to the various challenges and the impact of globalization, which confronted the dilemma choices. On the one hand, globalization is seen by local cultures as an 'opportunity' for developing your own potential and advantages in a complex terrain of global competition, on the other hand, globalization seen also as a 'threat' (threat) to the existence and sustainability of local culture itself. Globalization is 'heterogenization' once 'homogenization'.

If it is so strong homogenizing force, then the local culture can be dragged in homogenizing forces, which threaten the sustainability and existence, and lose their identity. On the other hand, if the local culture does not do self-development, local benefits of the creation of opportunities that just "taken over" by the outside parties concerned, the form of 'theft' and 'annexation' culture, to 'change' in accordance with the global capitalist economy.

In such a dilemma situation, efforts to create a 'local advantage' (local genius) can be viewed as a strategy, so that local culture can actualize itself within the global context, and on the other hand avoid the influence of cultural homogenization (cultural homogenization). For that, the excavation of local excellence requires different thinking, both at the level of philosophical, economic, sociological and cultural, that is expected to open up opportunities for the enrichment of local culture, by creating space for the development of 'local creativity' or 'cultural innovation', without having to value-Value of sacrificing principle.

In the effort to create a local advantage in the context of globalization, at least there are two problems that arise, namely 1) how to develop local excellence itself, based on the resources of existing local knowledge: concepts, strategies and methods, 2) how the local advantage can be placed in the context of global competition today. In other words, the effort of understanding and developing a local benefits are an integral part in the understanding of global culture, with many paradoxes and contradictions that exist therein.

How to change a tradition? In this case, there is a general assumption, that tradition does not have the power of knowledge, creativity, need of achievement or progressive mental attitude, which encourages the direction of change. However, this is certainly a very ideological view about society and ethnocentric tradition. Instead, each tradition has a system of 'knowledge' itself, which is called local knowledge, local psychology and local aesthetics, with all its potential for development and progress. However, local knowledge is not getting an opportunity for the systematic 
development and incentives, so that he left behind from the modern western knowledge. If there are ideas and incentives and systemic reinterpretation of traditions in new contexts (re-contextualization), he was also able to generate innovation (indigenous innovation), innovation is rooted in the problems, resources, and the psychology of creation and local creativity.

Strategy development of painting like to generate local benefits, can be explained as follows:

First, the reinterpretation strategy (reinterpretation). Various sources of wealth of philosophy, knowledge, technology, skills, materials and local aesthetics should be in the context of painting like should reinterpretation within the context of the present. Reinterpretation that gives new meaning to an object leaving from the meanings that already exist, without destroying its essential values. In the exploration of the aesthetic appreciation of the uniqueness indispensable place (place), human, knowledge and indigenious culture. However, also required the expansion of awareness about the importance of insight knowledge, enrichment of the language and idioms, and the increasing complexity of the aesthetic, through a reinterpretation of the aesthetic (an aesthetic reinterpretation) of local expressions, based on the consideration that the identity, value and meaning of aesthetic (aesthetic meaning) is seen as something that was never finished (the definite), always open to interpretation or meaning, new meanings (interpretation of interpretation), in a process that has always been (Becoming).

Second, transesthetic crossings strategy. Local cultural development opportunity for a (or several) line crossings between a local culture or other cultural resources, in an arena dialogistic cultural (cultural dialogism). That is, the development of painting like the opportunity for a process of cultural meetings and even cultural exchanges (cultural exchange), to produce shapes or formations rich, different and diverse. In exchange they are formed in the fabric of a reciprocal process of giving each other, influence each other, enriching each other or push each other to the various possible forms, expressions or a new formation. Various lines are very rich dialogue is expected to produce shapes, concepts, ideas, idioms, language phrase that was not imagined before. Although, in the process of exchanging it certainly needed to play together in a constructive rules.
Third, the dialogistic cultural strategye (cultural dialogism). Meeting a culture of (local) with another culture involves the selection process, intercultural exchange and influence the complex, which can actually be positive, constructive and productive for the development of local culture itself. What makes the local culture enthusiastically accept foreign culture, is the spirit to build a common denominator of culture through a process of mutual exchange of culture (cultural exchange).

Fourth, openness strategy-critical (critical openness). Local cultural development process, in order to find a local advantage, according to an attitude of openness to various cultures enter from outside (foreign). However, this openness must be accompanied or inklusifisme critical attitude, the ability to assess foreign culture, thus creating a kind of critical openness. Local culture to open up to various developments, discoveries and new innovations in every field from various foreign sources or external, which interact, which is based on attitude of inclusiveness and tolerant, that is an attitude that does not put a prejudice against foreign cultures, but is able to view it more positively, constructively but also analytical and critical, as long as he did not threaten local values itself. This critical attitude is needed in order to filter out the negative aspects that threaten the basic values of local culture, but instead will accept the positive aspects for the enrichment of local culture itself.

Fifth, the strategy of differentiation of local knowledge. Development of local culture can not be done without increasing the quantity and quality of research and knowledge development, through various research and development activities of local knowledge and indigenous knowledge. Research and development of local cultural knowledge is expected to explore the sources of local knowledge (local knowledge) or knowledge of ethnic (indigenous knowledge) that is very unique and rich, so it can produce something new. In this study, it should be an emphasis on objects, problems and indigenous approaches, which are expected to produce a variety of unique cultural products, different and original.

Sixth, a strategy of lifestyle (life style), which is studying changes in lifestyles, by following the new development trend. lifestyle changes is very important to be known by every party to the process of innova- 
tion, product, form, function, image or a certain style of local products, due to no longer suitable to the lifestyle of the sapling. Understand the lifestyle change means understanding the changes in the patterns of use of space, time and goods. Many products have failed, due to the designer and the producers failed to understand the changing lifestyle of consumers.

\section{CONCLUSION}

Balinese cultural exchange motivate people to do the filtering process, organize, separate, select and decide, in an intercultural meeting productive. It involves a process of mutual exchange of learning, playing and competing with each other which was framed by the rules (rules of the game) so the absence of negative conflicts that could open new insights in the process if the copyright, a sense of creativity and initiative as the basis of art.

Painting has been moved to follow the development progress of the age, from classical to traditional and developing and moving towards modernization and post modern. Although the resulting experience renewal, but the beauty of its lines and the power generated by the force and the object-object remains strong roots in the traditions of Bali, which is the defense aspect inherited by generations.

Market dynamics, especially the tourism market has been and will run affect each other. Economization (capital) in the context of painting in Bali has been a life support system and the ongoing creation. A patron of artists and works, continuity growth pattern of the 1930s when Neuhaus holds the artery was still going on the market today.

Acknowlegment:

Thank to I Gusti Made Sutjaja (translation)

\section{REFERENCES}

Bagus, I Gusti Ngurah. (2001), "Reformasi, Multikulturalisme, dan Masalah Politik Bahasa di Indonesia”, Makalah Seminar di Program Studi S2 dan S3 Kajian Linguistik Universitas Udayana Denpasar-Bali pada tanggal 25 Mei 2001.
Barrucha, Rustom. 1998/1999. “Interkulturalisme dan Multikulturalisme di Era Globalisasi: Diskriminasi, Ketidakpuasan, dan Dialog”. Jurnal Seni Pertunjukan Indonesia Th. IX: Bandung: MSPI.

Couteau, Jean. (2002), Wacana Seni Rupa Bali Modren, dalam Paradigma Pasar Aspek-Aspek Seni Visual Indoneisa, Yogyakarta, Yayasan Cemeti.

Djelantik, A.A.M. (1996), Pengantar Dasar Ilmu Estetika I, Denpasar, STSI Denpasar.

Hartiningsih, Maria. (200), “Asimilasionisme vs Multikulturalisme”, Jakarta, Kompas, Rabu 14 Maret 2001.

Haviland, William A. (1988), Antropologi. Jilid I dan II (Terjemahan R.G. Sukardjito), Jakarta, Erlangga.

Holt, Claire. (2000), Melacak Jejak Perkembangan Seni di Indonesia (Terjemahan R.M. Soedarsono), Bandung, Arti Line untuk MSPI (Masyarakat Seni Pertunjukan Indoneia).

Kusnadi. (1990-1991), “Seni Rupa Indonesia di Masa Perintisan”, dalam Perjalanan Seni Rupa Indonesia dari Zaman Prasejarah Hingga Masa Kini, Panitia Pameran KIAS.

Kanta, I Made. (1977/1978), Proses Melukis Wayang Kamasan, Denpasar, Proyek Sasana Budaya Bali.

Nieto, Sonia. (1992), Affirming Diversity: The Sociopolitical Context of Multicultural Education, New York, Longman.

Pitana, I Gede. (1994) Dinamika Masyarakat dan Kebudayaan Bali, Denpasar, Bali Post

Rahzen, Taufik. (1998/1999), “Keragaman dan Silang Budaya: Mencari Beberapa Agenda” dalam Jurnal Seni Pertunjukan Indonesia Th. IX, Bandung, MSPI.

Salim, Agus, (2002), Perubahan Sosial Sketsa Teori Refleksi Metodologi Kasus Indonesia, Yogyakarta, Tiara Wecana Yogya. 
Sudarmaji. (1977), Derent Styles of Painting in Bali, Gianyar, Yayasan Dharma Seni Museum Neka Ubud.

Suwarsono, Alvin Y.So. (1994), Perubahan Sosial dan Pembangunan, Jakarta, Pustaka LP3ES.

Soedarso, Sp. (2005), Pelacakan Sini Lukis Indonesia Tradisional Melalui Relief-Relief Candi, Kidung, Wayang Beber, Seni Lukis Tradisional Bali,(Materi Kuliah), Yogyakarta, PPS ISI
Vikers, Adrian. (1998), "Peran Koleksi Lukisan Neuhaus dalam Sejarah Seni Lukis Bali”, dalam Jurnal Lontar No. 09/Th.III/Triwulan I/ 1998.

Yudoseputra. (1990), Teori-teori Perubahan Sosial, Bandung, Program Pasca Sarjana Universitas Padjajaran. 